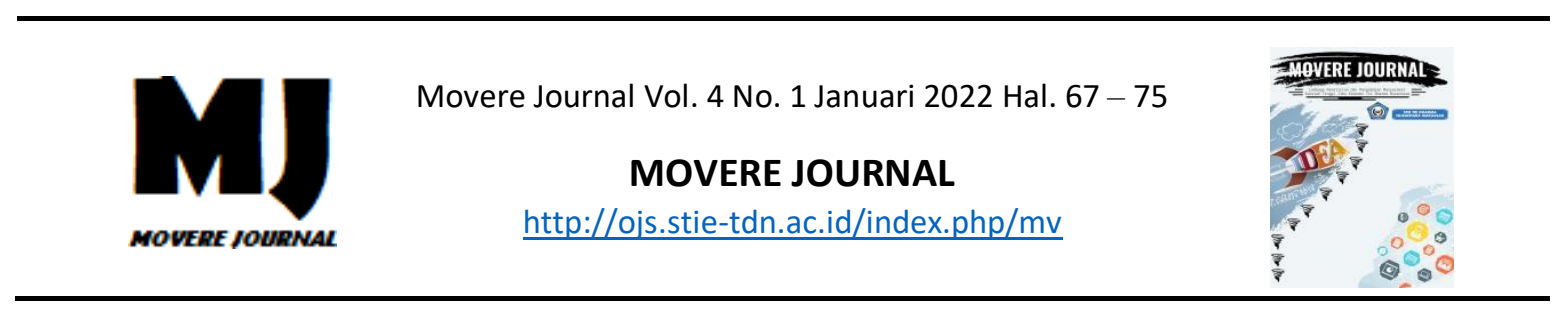

\title{
Pengaruh Pendidikan Kewirausahaan Terhadap Niat Berwirausaha Mahasiswa
}

\author{
Nurfatwa Andriani Yasin ${ }^{1}$, Muhammad Nasir ${ }^{2}$ \\ STIE Tri Dharma Nusantara ${ }^{1}$, Universitas Pejuang Republik Indonesia ${ }^{2}$ \\ Email : nurfatwaandriani@gmail.com
}

\begin{abstract}
Abstrak: Penelitian ini bertujuan untuk mengetahui pengaruh pendidikan kewirausahann terhadap niat berwirausaha pada mahasiswa fakultas ekonomi di Universitas Pejuang Republik Indonesia. Penelitian ini menemukan bahwa ada pengaruh positif dan signifikan antara Pendidikan kewirausahann terhadap niat berwirausaha pada mahasiswa fakultas Ekonomi di Universitas Pejuang Republik Indonesia. Dengan formulasi persamaan liner $Y=2,272+\mathbf{0 . 4 8 3} X_{I}$. R square sebesar 0.197 yang berarti bahwa niat untuk berwirausahan para mahasiswa dipengaruhi oleh pendidikan kewirausahaan sebesar 19,7\%. Penelitian ini menyimpulkan bahwa pendidikan kewirausahaan mampu menyampaikan pengetahuan yang dibutuhkan dan memberikan keterampilan yang mampu mengubah niat mahasiswa untuk berwirausaha menjadi kegiatan wirausaha. Meskipun pendidikan kewirausahaan bukanlah hal yang mutlak mengarah pada niat berwirausaha, namun pendidikan kewiraushaan ini memiliki cara tersendiri untuk memotivasi mahasiswa dalam memulai usaha wirausaha.
\end{abstract}

Kata Kunci: Pendidikan Kewirausahaan, Niat Berwirausaha, Mahasiswa

Abstract: This study aims to determine the effect of entrepreneurship education on students of the Faculty of Economics, Pejuang University of the Republic of Indonesia. This study found that there was a positive and significant effect between entrepreneurship education on entrepreneurial intentions in students. With the formulation of the linear equation $Y=2.272+0.483$ X1.R square is 0.197 which means that the students' intention to become entrepreneurs is influenced by entrepreneurship education by 19.7\%. This study concludes that entrepreneurship education is able to convey the required knowledge and provide skills that are able to change students' intentions to become entrepreneurs into entrepreneurial activities. Although entrepreneurship education is not an absolute thing that leads to entrepreneurial intentions, this entrepreneurship education has its own way of motivating students to start entrepreneurial businesses.

Keywords: Entrepreneurship Education, Entrepreneurial Intentions, Students 


\section{A. PENDAHULUAN}

Tujuan dari penelitian ini adalah untuk menguji efek dari pendidikan kewirausahaan pada niat kewirasusahaan mahasiswa dan untuk mengetahui sejauhmana mahasiswa memiliki niat untuk berwirausaha setalah mendapatkan pendidikan kewirausahan (Maki 1999; Douglas dan Dean 2002; Dean, 2004). Efek dari pendidikan kewirausahaan telah memberikan efek untuk memulai usaha atau bisnis pada negara-negara seperti dan Amerika Serikat, Prancis, Jerman, Inggris untuk menyebutkan beberapa. Gartner dan Vesper, (1974); Fayolle (2004) mengatakan bahwa sekarang banyak lembaga pendidikan yang menawarkan berbagai kegiatan program dan pelatihan kewirausahaan. Program ini tampaknya mempengaruhi mahasiswa untuk masuk kedalam bisnis mereka. Souitaris, Zerbinati dan Al-lahan (2006) mengungkapkan bahwa program kewirausahaan meningkatkan sikap dan perilaku di kalangan pemuda untuk berwirausaha demi kepentingan pembangunan ekonomi bangsanya. Demikian pula hasil penelitian yang dilakukan oleh Karl Eller (2000) Program Kewirausahaan Center-Berger, University of Arizona menunjukkan bahwa (i) pendidikan kewirausahaan meningkatkan kemungkinan munculnya usaha atau bisnis baru sebesar $25 \%$ (ii) lulusan tiga kali lipat lebih mungkin untuk menjadi wiraswasta; (iii) lulusan menerima pendapatan tahunan $27 \%$ lebih tinggi dan memiliki $62 \%$ memiliki banyak aset dan (iv) lebih puas dengan pekerjaan (wiraswasta).
Memulai wirausaha di antara siswa tidak hanya meningkatkan gaya hidup ekonomi mereka tetapi membantu mendorong pembangunan ekonomi. Ini membuat universitas menjadi sangat popular di kalangan industri. Ini mengarah pada kemunculan dan difusi yang kuat dari jiwa wirausaha di lingkungan kampus universitas (Fayolle, 2004). Terlepas dari pentingnya kewirausahaan pembangunan ekonomi, peran mahasiswa dalam memajukan kewirausahaan sebagian besar masih belum dipelajari. Jadi sanagt penting untuk mengetahui tentang faktorfaktor yang mempengaruhi niat mahasiswa untuk berwirausaha secara teoritis dan implikasi agara pembuat kebijakan bisa memperhatikan hal tersebut.

Penelitian kali ini berfokus pada niat kewirausahaan mahasiswa untuk melakukan kegiatan kewirausahaan setelah mereka lulus. Beberapa dari pertanyaan spesifik yang ada di benak kami selama penelitian meliputi; apakah pendidikan kewirausahaan benar-benar mempengaruhi mahasiswa? Bagaimana niat untuk memulai sebuah usaha? apakah motivasi mahasiswa untuk berwirausaha berhubungan dengan pendidikan kewirausahaan mereka? Penelitian ini mengambil responden dari mahasiswa jurusan manajemen dan bisnis pada Universitas Pejuang Republik Indonesa dengan jumlah responden sebesar 80 mahasiswa pada tingkat akhir.

\section{B. TINJAUAN TEORI}

\section{Kewirausahaan}

Pendidikan kewirausahaan difokuskan pada pengembangan generasi 
muda dengan semangat dan berbagai keterampilan. Hal ini bertujuan untuk mengurangi risiko yang terkait dengan pemikiran kewirausahaan dan membimbing perusahaan berhasil melalui tahap awal ke tahap kedewasaan. Menurut Brown (2000) kewirausahaan pendidikan dirancang untuk berkomunikasi dan menanamkan kompetensi, keterampilan, dan nilai yang diperlukan untuk mengenali peluang bisnis, atur dan mulai bisnis baru usaha. Gorman, Hanlon, dan King, (1997) menunjukkan bahwa pendidikan kewirausahaan adalah program pendidikan yang difokuskan pada mahasiswa dengan melihat danpak dan masalah dari pada kewiraswastaan. Pendidikan kewirausahaan telah melalui melalui beberapa tahap perkembangan. Postigo dan Tamborini (2007) dalam studi mereka meninjau dan menganalisis empat garis penelitian yang dijelaskan secara rinci fenomena ini di negara yang berbeda. Ini termasuk; (i) studi tentang dampak bahwa pendidikan kewirausahaan di universitas tingkat menurut Price dan Monroe, (1993); Charney dan Libecap, (2000); (ii) analisis atas instrumen pedagogik dan metodologi yang digunakan untuk mengajar kewirausahaan (Plaschka dan Welsch, 1990; Laukannen, 2000); (iii) penelitian terkait pendidikan kewirausahaan mutakhir (Vesper dan Gartner, 1997) dan (iv) melaporkan pengalaman praktis pada tingkat pendidikan yang berbeda (Mason, 2000; Solomon, Duffy, dan Tarabishy, 2002). Studi lain juga menyebutkan apa isi dari pendidikan kewirausahaan yang baik? program yang berorientasi pada keterampilan. Ini termasuk; kepemimpinan, negosiasi, pemikiran kreatif, paparan teknologi, penemuan dan inovasi (McMullan dan Long, 1987; Vesper dan McMullen, 1998); peluang identifikasi, modal ventura, pembangkitan ide dan perlindungan, toleransi terhadap kemampuan, kemampuan mengatasi tantangan pada tahap kewirausahaan yang berbeda, ciri-ciri kepribadian, kemampuan untuk menulis dan mengkomunikasikan rencana bisnis, usaha baru pengembangan, kemampuan untuk mendiagnosis kinerja bisnis, jaringan dan bimbingan, analisis lingkungan, keterampilan komputer dan simulasi, studi kasus, film dan videoing, analisis lapangan dan perusahaan (Plaschka and Welsch, 1990; Kuratko, 2005).

Sementara kewirausahaan adalah sebuah konsep yang melibatkan aktivitas mental seperti kreativitas, inovasi dan proaktif, pendidikan perusahaan dirancang untuk mempersiapkan siswa untuk terlibat dalam masa depan ekonomi yang diarahkan sendiri seperti mencari peluang, mengambil risiko dan memiliki keuletan untuk mendorong ide menjadi kenyataan digabungkan menjadi sebuah perspektif khusus yang merasuki para wirausahawan (Adenipekun, 2004). Menurut Garavan, Costine, dan Hegarty (1995) pendidikan perusahaan adalah proses atau serangkaian kegiatan yang bertujuan untuk memungkinkan seorang individu untuk mengasimilasi dan mengembangkan pengetahuan, keterampilan, nilai-nilai dan pemahaman yang tidak hanya terkait dengan bidang kegiatan yang sempit, tetapi yang memungkinkan berbagai masalah untuk didefinisikan, dianalisis dan dipecahkan. Ini berfokus pada pengembangan siswa dengan semangat dan keterampilan yang dibutuhkan untuk menciptakan perusahaan kewirausahaan yang berisiko secara inheren dan 
membimbing perusahaan dengan sukses melalui tahap awal hingga tahap kedewasaan. Ini mengkomunikasikan dan menanamkan keterampilan yang dibutuhkan untuk mengenali peluang bisnis, pengorganisasian dan proses memulai usaha bisnis baru (Brown, 2000). Tujuannya adalah untuk membantu kaum muda mengembangkan keterampilan dan atribut yang memungkinkan mereka untuk menjadi inovatif dan untuk mengidentifikasi, memulai dan berhasil mengelola pribadi dan kesempatan kerja, termasuk bekerja untuk diri mereka sendiri (Walstad, dan Kourilski, 1999; Bhandari, 2006; Uwameiye dan Uwameiye, 2006).

Menghubungkan pendidikan dengan kewirausahaan, studi oleh para sarjana yang berbeda mengungkapkan bahwa ada perspektif dan pendekatan yang berbeda yang dapat diadopsi (Robinson dan Sexton, 1994; Kolvereid dan Moen, 1997; Delmar dan Davidson, 2000; Charney dan Libecap, 2000; Cowling dan Taylor, 2001; Levie., 2001; Lüthje dan Franke, 2002 dikutip dalam Thandi dan Sharma 2003). Adopsi pendekatan ini tergantung pada keputusan kelembagaan dan desain program. Selain pengaturan ruang kelas formal, peneliti berpandangan bahwa kewirausahaan juga dapat dikomunikasikan melalui konferensi, seminar, publikasi jurnal, program lokakarya dan menggunakan platform pusat penelitian (Adenipekun, 2004; Uwameiye dan Uwameiye, 2006; Miettinen, 2006). Peningkatan kualitas pendidikan kewirausahaan di lembaga kami meningkatkan tingkat sikap pemuda terhadap pengembangan kewirausahaan. Seperti yang diprediksi oleh Vesper (1974) pendidikan kewirausahaan adalah salah satu bidang yang telah mengembangkan pengetahuan yang relevan di zaman kita. Mengevaluasi pengaruh pendidikan terhadap kewirausahaan, Miettinen (2006) berpendapat bahwa banyak penekanan ditempatkan pada interaksi antara pendidikan dan industri, pertukaran ahli dan transfer pengetahuan dari lembaga pendidikan ke bisnis. Pendidikan baik tentang atau untuk kewirausahaan (Laukannen, 2000; Luthje dan Franke, 2003; Rostini R, 2012) membantu dalam penciptaan bisnis baru, pengembangan proses kewirausahaan dan isu-isu yang berkaitan dengan teori dan manajemen usaha kewirausahaan.

\section{Niat Berwirausaha}

Apakah motivasi mahasiswa untuk berwirausaha berhubungan dengan pendidikan kewirausahaan mereka? Faktor motivasi dari mahasiswa yang lulus itu berbeda- untuk memulai sebuah perusahaan. Penekanan universitas pada pengetahuan dan kinerja akademik yang berbasis kewirausahaan sebagai salah satu syarat kelulusan mahasiswa dapat mendorong dan memprovokasi tindakan kewirausahaan di kalangan mahasiswa. Villanueva, (2005) menyajikan bukti rinci tentang faktor-faktor yang dapat diperdebatkan yang berkaitan dengan kemungkinan setiap hasil dan implikasinya terhadap kegiatan kewirausahaan universitas. Namun, usaha kewirausahaan mungkin muncul dari kelas pendidikan kewirausahaan tertentu bahkan di mana banyak mahasiswa tidak pernah memiliki niat untuk memulai bisnis. Alasan di balik ini adalah karena dalam banyak kasus, mahasiswa ditekan oleh pengajar di universitas mereka atau 
kebijakan program atau ketersediaan hibah (yang menekankan pada pendaftaran mahasiswa dari bisnis mereka sendiri) untuk memulai bisnis saat masih di sekolah sebagai indikasi kewirausahaan mereka. Niat ini telah menciptakan tantangan untuk tidak memiliki perbedaan yang jelas antara pendidikan kewirausahaan dan niat mahasiswa yang sebenarnya untuk memulai bisnis. Thandi dan Sharma (2003) mengembangkan kerangka konseptual untuk menunjukkan hubungan antara faktor anteseden (penggerak kewirausahaan), variabel intervensi atau pendidikan kewirausahaan (fasilitator kewirausahaan) dan niat kewirausahaan (tindakan atau hasil kewirausahaan) di antara siswa. Menurut mereka, pendidikan kewirausahaan berperan sebagai variabel intervening terhadap niat seseorang untuk memulai usaha wirausaha. Niat berwirausaha ditujukan untuk menciptakan usaha baru atau menciptakan nilai baru dalam usaha yang sudah ada (Vesalainen dan Pihkala, 1999). Teori ini menurut Thandi dan Sharma (2003) mengemukakan bahwa sikap seseorang terhadap menjadi wirausaha, norma subjektif (persepsi orang lain), dan kontrol perilaku merupakan anteseden niat. Artinya sikap, norma subjektif dan perilaku yang dirasakan mengendalikan tindakan (motivasi). Jadi, semakin disukai sikap dan norma subjektif dan semakin besar kontrol perilaku yang dirasakan, semakin kuat niat untuk melakukan perilaku tersebut. Teori perilaku terencana telah berhasil digunakan untuk memprediksi niat dalam berbagai aplikasi (Kruegar dan Carsrub, 1993).

\section{METODE PENELITIAN}

Penelitian dini dilakukan pada Universitas Pejuang Republik Indonesia dengan populasi seluaruh mahasiswa ekonomi jurusan manajemen. Sampel dalam penelitian adalah semua mahasiswa tingkat akhir dengan jumlah 80 orang. Metode analysis yang digunakan adalah uji t dengan bantuan program SPSS.

\section{DATA ANALISIS}

$\mathrm{H} 0=$ Tidak ada pengaruh signifikan antara Pendidikan

Kewirausahaan Terhadap Niat Berwirausaha Mahasiswa

$\mathrm{H} 1$ = Ada pengaruh signifikan antara Pendidikan Kewirausahaan Terhadap Niat Berwirausaha Mahasiswa

\section{Tabel 1. Uji T}

\section{Coefficients $^{\mathrm{a}}$}

\begin{tabular}{|l|c|c|c|c|c|c|}
\hline \multirow{2}{*}{ Model } & \multicolumn{2}{|c|}{$\begin{array}{c}\text { Unstandardized } \\
\text { Coefficients }\end{array}$} & $\begin{array}{c}\text { Standardized } \\
\text { Coefficients }\end{array}$ & $\mathrm{t}$ & Sig. & R Square \\
\cline { 2 - 7 } & $\mathrm{B}$ & Std. Error & Beta & & & \\
\hline $1 \quad$ (Constant) & 2,272 &, 443 & & 5,127 &, 000 & 0.197 \\
\hline
\end{tabular}




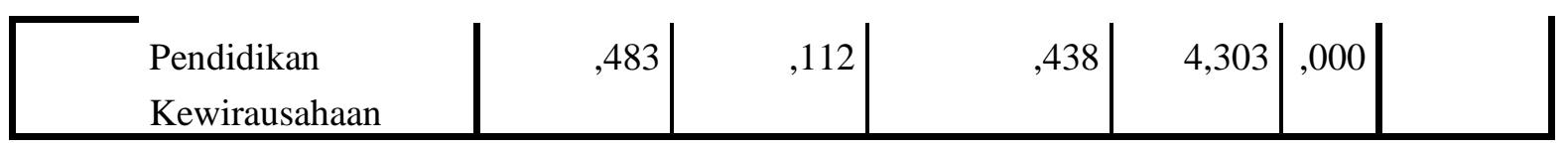

a. Dependent Variable: Niat Berwirausaha

Dari table 1 diatas dapat dirumuskan

fungus regresinya sebagai berikut:

$Y=2,272+0.483 X_{I}$

$\mathrm{a}=2,272$ artinya jika $\mathrm{X}_{1}$ (Pendidikan

Kewirausahaan $)=0$, maka niat berwirausaha mahasiswa sebesar 2,272 .

$\mathrm{b}_{1}=0,483$ menunjukkan bahwa jika variabel pendidikan kewirausahaan $\left(\mathrm{X}_{1}\right)$ meningkat sebesar $1 \%$, maka niat berwirausaha mahasiswa akan meningkat sebesar 0,483 dengan.

Selanjutnya dengan melihat table 1 nilai dari t hitung sebesar 4,303 dengan nilai t table sebesar 1,99 sehingga hal ini membuktikan bahwa ada pengaruh yang signifikan antara pendidikan kewirausahan dengan niat berwirausahan mahasiswa. $\mathrm{H} 0$ ditolak dan $\mathrm{H} 1$ diterima. $\mathrm{R}$ Square sebesar 0.197 yang berarti bahwa niat berwirausaha mahasiswa dipengaruhi oleh adanya pendidikan kewirausahaan sebesar $19.7 \%$.

\section{E. PEMBAHASAN}

Dari hasil analisis data diperoleh bepengaruh postif kepada minat motivasi atau keinginan mahasiswa menjadi seorang wirausahaan dengan memilai sebuah usaha atau bisnis. Di antara semua karakteristik wirausaha seperti keinginan untuk berprestasi, Locus of control, berani mengambil risiko, proaktif, dan toleransi untuk ambiguitas, inovasi dan kreativitas diyakini melekat bagi seorang pengusaha. Adanya niat mahasiswa untuk memulai suatu usaha atau bisnis memerlukan suatu kesiapan mental dan pengetahuan khusus untuk menjadi seorng pengusaha, dan sebagian besar ciri ciri wirausaha itu sudah napak pada sebagian besar mahasiswa selama pendidikan kewirausahaan itu mereka dapatkan di bangku kuliah.

Awalnya dikalangan mahasiswa minat menjadi seorang wirausaha masih sangat minim, karena sebagian besar mahasiswa masih berpikir bahwa kuliah untuk membuat kita menjadi seorang karyawan atau pegawai. Selain itu, ada beberapa faktor yang mengakibatkan mahasiswa kurang berminat buat berwirausaha yaitu tak ada sumber daya modal untuk memulai usaha, atau mereka tidak pernah dibekali dengan ilmu pengetahuan tentang kewirausahaan.

Setelah pendidikan kewirausahaan hadir disetiap Lembaga Pendidikan Tinggi, maka hal inilah yang menjadi jembatan bagi mahasiswa untuk dapat membangun minat dan motivasi berwirausaha mereka. Mereka mampu melihat peluang yang ada disekitarnya. Banyak manfaat yang diperoleh melaui pendidikan kewirausahan ini seperti meningkatkan keterampilan mahasiswa dalam bidang kewirausahaan agar tercipta kader pengusaha muda yang berpotensi, mahasiswa akan berusaha memenuhi kebutuhannya sendiri, mampu menciptakan lapangan kerja sehingga hal 
ini membantu pihak pemerintah untuk mengurangi masalah pengangguran.

Penelitian ini bertujuan untuk menguji pengaruh pendidikan kewirausahaan terhdapa niat berwirausaha mahasiswa. Studi ini memperjelas bahwa karakteristik kewirausahaan kaum muda sangat beragam dan efek dari pendidikan kewirausahaan yang mereka dapatkan selama emapt tahun mampu memprovokasi mereka untuk menjadi pengusaha. Ini juga merupakan indikasi bahwa mereka telah dilengkapi dengan pengetahuan yang mereka perlukan dan keterampilan yang dibutuhkan untuk memulai usaha baru. Selain itu mereka beranggapan bahwa pendidikan kewirausahaan sangat bermanfaat untuk membantu majikan atau manajer atau mengelola bisnis mereka sendiri. Pentingnya program pendidikan kewirausahaan ini adalah untuk memperkenalkan kewirausahaan di lembaga tinggi, untuk membekali mahasiswa dengan keterampilan dan pola pikir yang diperlukan untuk sukses menjadi wirausahaan, dan juga untuk menanamkan kepada mahasiswa di semua tingkat pendidikan, tentang kepercayaan diri dan jaminan yang diperlukan untuk memulai bisnis.

Pendidikan menyampaikan pengetahuan yang dibutuhkan dan memberikan keterampilan yang mampu mengubah niat mahasiswa untuk berwirausaha menjadi kegiatan wirausaha. Meskipun pendidikan kewirausahaan bukanlah hal yang mutlak mengarah pada niat berwirausaha, namun pendidikan kewiraushaan ini memiliki cara tersendiri untuk memotivasi mahasiswa dalam memulai usaha wirausaha. Juga, ada kecenderungan bahwa tidak semua mahasiswa yang memiliki niat untuk memulai usaha wirausaha akan berakhir sebagai pengusaha.

Penelitian ini merekomendasikan bahwa untuk mewujudkan pendidikan kewirausahaan sangat penting peran institusi untuk menyusun strategi dalam membantu mahasiswa yang menunjukkan niat mereka untuk memulai usaha saat di kampus dan setelah lulus mereka bisa bergabung dengan beberapa incubator program kewirausahaan dari kampus. Hal Ini akan membantu mendorong lebih banyak mahasiswa untuk menjadi serius dengan niat mereka untuk menjadi pengusaha. Karena dana merupakan faktor penting dalam melaksanakan niat untuk berwirausaha, maka mahasiswa harus belajar untuk membudayakan budaya menabung sejak mereka masih duduk di bangku sekolah atau kuliah karena tabungan ini diperlukan untuk memulai suatu bisnis.

\section{DAFTAR PUSTAKA}

Adenipekun, O. (2004), "Unemployment: Varsities and Entrepreneurial Courses to Curriculum”. Lagos: The Guardian.

Bhandari, N. C. (2006), "Intention for Entrepreneurship among Students in India”. The Journal of Entrepreneurship, Sage Publication, 15(2), 169-179.

Brown, C. (2000), "Entrepreneurial education Teaching Guide", Kansas City. M O: Kauffman Centre for 
Entrepreneurial Leadership ClearingHouse on Entrepreneurship Education. 1-13.

Charney, A. and Libecap, G. (2000), "Impact of Entrepreneurship Education." Insights: A Kauffman Research Series. Kauffman Centerfor Entrepreneurship Leadership.

Dean, A. S. (2004), "Educating Entrepreneurship Students About Emotion and Learning From

Douglas, E. J. and Dean, S. A. (2002), "Self- employment as a Career Choice: Attitudes

Fayolle, A. (2004), "Value Creation in Changing Student State of Mind and Behaviour: New Research Approaches to Measure the Effects of Entrepreneurship Education," A study carried at by the Research unit of Entrepreneurship and Processes of Innovation.

Garavan, T., Costine, P. and Hegarty. N. (1995),Training and Development in Ireland Context, Policy and Practice, Oak Tree Press, Dublin.

Gorman, G., Hanlon, D., and King, W. (1997), "Some Research Perspectives on Entrepreneurship Education, Enterprise Education and Education for Small Business Management: a Ten-Year Literature Review", International Small Business Journal. Vol. 15 No.3.

Karl Eller Centre-Berger Entrepreneurship Program (2000), "Entrepreneurship Education Impact Study: Findings Summary”,
University of Arizona, Tucson, Arizona,June, 1-2.

Kuratko, D. F.(2005), “The Emergence of Entrepreneurship Education: Development, Trends, and Challenges", Entrepreneurship Theory and Practice.

Laukannen, M (2000), “Exploring Alternative Approaches in Highlevel Entrepreneurship Education: Creating Micro Mechanisms for Endogenous Regional Growth." Journal of Entrepreneurship and Regional Development; 12.

Luthje, C., Franke N. (2003), "The „Making of an Entrepreneur: Testing a Model of Entrepreneurial Intent Among Engineering Students at MIT", $R \& D$ Management 33, (2), $135-147$

Maki, K. (1999), "Motivation for Entrepreneurship Among Academics". Research Paper

Mason, C. (2000), "Teaching Entrepreneurship to Undergraduate: Lessons from Leading Centers of Entrepreneurship Education", University of Southampton. Department of Geography

McMullan, W.E. and Long, W. A. (1987), "Entrepreneurship Education in the Nineties". Journal of Business Venturing, 2, 261-275.

Price, C. and Monroe, S. (1993),"Educational training for woman and minority entrepreneurs ositively impacts venture growth and economics development." Frontiers of Entrepreneurship Research, 


\section{Babson College.}

Plaschka, G. R. and Welsch, H. P. (1990), "Emerging Structures in Entrepreneurship Education: Curricula Designs and Strategies." Entrepreneurship Theory and Practice, 14(3), 55-71.

Postigo, S. and Tamborini, M. F. (2007), "University Entrepreneurship Education in Argentina: Decade of Analysis", National Council for Graduate Entrepreneurship Working Paper 014, 1-12.

Rostini, R., Souisa, W., Masmarulan, R., \& Yasin, N. (2021). Competitiveness development, learning orientation, entrepreneurial commitment and business performance in the silk industry. Management Science Letters, 11(3), 903-908.

Solomon, G., Duffy, S. and Tarabishy, A. (2002), "The State of Entrepreneurship Education in he United States: A Nationwide Survey and Analysis." International Journal of Entrepreneurship Education, 1 (1).

Somtaris, V. S. Zerbinati, S. and Al-Lahan (2006), “ Do entrepreneurship Programme Raise Entrepreneurial Intention of Science and Engineering
Students? The Effect of Rearning, Inspiration and Resources". Journal of Business Venture, 22(4)

Thandi, H. and Sharma, R. (2003), "MBA Students and Entrepreneurship: An Australian Study Entrepreneurial Intentions and Actualization, JIRSEA, 2(1) 1223.

Uwameiye, R. and Uwameiye, B. E. (2006), "Attitude of Nigerian University Students Towards Entrepreneurship Education", European Journal of Scientific Research, 15(2), 201-206.

Vesper, K. and Gartner, W. (1997), "Measuring Progress in Entrepreneurship Education." Journal of Business Venturing, 12 (5).

Vesper, K.H. and McMullen, W. E (1998), "Entrepreneurship: Today Courses, Tomorrow egress?" Entrepreneurship Theory and Practice.13(1), 7-13

Walstad, W. and Kourilski, .M (1999), Seeds of Success: Entrepreneurship and Youth, 5, 16-22 